\title{
EXPLORING THE ROAD MAP OF YOUNG NEWLY MARRIED MALAY COUPLES IN THE KLANG VALLEY ON THEIR QUEST FOR FINANCIAL WELL-BEING: A QUALITATIVE APPROACH
}

\author{
LEYLAWATI JOREMI $^{1 *}$, ROZA HAZLI ZAKARIA ${ }^{2}$ AND SITI HAJAR ABU BAKAR ${ }^{3}$ \\ ${ }^{I}$ Faculty of Business and Management, Universiti Teknologi MARA, 42300 Bandar Puncak Alam, Selangor, Malaysia \\ ${ }^{2}$ Faculty of Economics and Administration, University of Malaya, 50603 Kuala Lumpur, Malaysia \\ ${ }^{3}$ Faculty of Arts and Social Sciences, University of Malaya, 50603 Kuala Lumpur, Malaysia \\ *Corresponding author: leylawati@uitm.edu.my
}

Submitted final draft: 17 November $2020 \quad$ Accepted: 8 December 2020

http://doi.org/10.46754/jbsd.2021.03.002

\begin{abstract}
Financial management practices (FMP) are a road map to a higher level of financial wellbeing (FWB). By employing a qualitative method, this research aims to contribute to the existing literature by exploring the road map of newly married couples in pursuit of higher FWB. We focused on young Malay adults as Malaysian Insolvency Department and Agency Counselling and Debt Management (ACDM) reported that they are the most financially vulnerable group. This exploration provided insight into their plan of action to achieve higher FWB. We conducted in-depth interviews with seven couples sampled intensively. Each couple underwent three series of interviews where each series took between two and four hours for data enrichment to answer the research questions. To expose their understanding, the phenomenological method was used. Analyses revealed three emerging themes. Income insufficiency supports LCH theory to financial planning needs. Thrifty in wisdom and moonlighting are in line with utility theory. Besides the wisdom needed in distinguishing needs and wants, the willingness to postpone today's satisfaction creates an opportunity to enjoy better FWB in the future. The findings are beneficial to the Religious Offices and ACDM. FMP should be included in the pre-marital course to instil awareness among potential brides.
\end{abstract}

Keywords: Financial management practices, financial well-being, moonlighting, phenomenological method, thrifty

\section{Introduction}

Financial well-being (FWB) is a benchmark of an individual's financial satisfaction. The road map to higher FWB begins with good financial management practices (FMP). Young adulthood is a time when one's current financial position changes (Vosylis \& Klimstra, 2020). The challenge is to make relatively large financial decisions for the first time as soon as they start working. Frączek and Klimontowicz (2015) said that the financial literacy of younger individuals is poor, thus, prone to financial stress (Falahati $\&$ Sabri, 2015). Failure in managing personal and household finances effectively resulted in a lower level of FWB (Malone, Stewart, Wilson \& Korsching, 2010). It then increases household debt (Garðarsdóttir \& Dittmar, 2012), household conflicts (Horrocks, 2010) and an increase in the divorce rate (Hasbullah \& Razak, 2017).

Reports from the Malaysian Insolvency Department indicated that in 2019 the highest number of bankruptcy cases with a total of 4,574 were among individuals aged between 35 to 44 years. This was followed by individuals aged between 45 to 54 years (3,087 cases) and 2,603 cases involving individuals aged 25 to 34 years. 56.08 percent are Malays, followed by Chinese (25.88 percent), Indians (11.18 percent) and others (6.86 percent). Selangor recorded the highest number of bankruptcy cases at 3,088 cases followed by Kuala Lumpur (1,122 cases) while Johor became the third with 1,034 cases. 
In addition to this problem, failure to manage expenditure (Razak, Abidin, Yusof, Sakarji \& Nor, 2014) and dealing with debt burdens (Luna-Torres, McKinney, Horn \& Jones, 2018) have been the source of motivation to begin this study. Furthermore, there is a dearth of study related to FWB of young newly married Malay couples (YNMMC) in Malaysia. Thus, this study intends to explore the road map of the YNMMC in pursuit of a higher level of FWB using qualitative methods.

\section{Relevant Theories}

\section{Theory of Utility}

From an economic point of view, utility explains how individuals deal with scarcity to achieve optimum satisfaction. Bentham(1781) explained that utilities mean every property in an object capable of offering advantage, excitement and goodness and can prevent the destruction and dissatisfaction of the parties concerned. Utility implied the level of satisfaction or happiness that exhibits positive function as more consumption being made (Dutt, 2006).

Satisfaction also depends on the decisions taken along the planning horizon. Hence, in discussing satisfaction, it does not only involve the choices of whether to spend, to save or to invest but it also involves time period, present and future. Therefore, individual satisfaction also depends on the decisions taken along the planning horizon (Castro-Gonzales, Fernandez-Lopez, Rey-Ares \& RodeiroPazos, 2020). Present-oriented time horizon individuals will focus on current satisfaction. Whereas, the future-oriented time horizon, will sacrifice current satisfaction for higher levels of satisfaction in the future. In addition, the planning horizon allows individuals to become more experienced in evaluating an investment and thus be able to manage household finances more prudently (Fong, 2020).

In brief, utility theory explains that individual satisfaction depends on the individual's desire to achieve the objective which involves choices in obtaining the expected results. The utility theory is well suited as a basis in studying the extent to which newly married couples control themselves in an effort to achieve a higher level of financial well-being in the future. It is closely related to spending patterns and credit control.

\section{Life-cycle Hypothesis (LCH)}

The LCH suggests that individuals plan consumption and savings behaviours throughout their life cycle (Holzmann, Ayuso, Alaminos \& Bravo, 2019). An individual will choose the consumption that can maximize his expected lifetime utility while his instantaneous utility function is unchanged over time (Hurd \& Rohwedder, 2013). The life-cycle theory of consumption asserts that individuals plan their consumption to smooth their consumption over a lifetime (Kim, Yoon \& Zurlo, 2012). Hudomiet, Hurd, Parker and Rohwedder (2019) said that by working longer and delaying retirement it helps individuals maintain their standard of living after retirement by increasing their lifetime income. It allows retired households to use and invest from previous resource optimizations (Hou, 2020).

The life-cycle theory of savings anticipated that the amount of savings increases with the increase in income (Dornbusch \& Fischer, 1994). Japelli and Modigliani (2005) stated that savings were driven by awareness to prepare the need for retirement. Generally, the human life-cycle shows different levels of consumption according to age. To satisfy the desire, households applied for credit. They believed that debt was a way to ease their expenses over time. Households were inclined to borrow when their income was relatively low and loans will only be repaid when income was high (Wickramasinghe \& Fernando, 2017). Individuals became more comfortable in spending due to easy credit card facilities which show that the credit limit increases rapidly which is more than 400 percent at the beginning of life and this mostly happens around the age of 20 to 30 years (Fulford \& Schuh, 2015).

As a conclusion, the $\mathrm{LCH}$ states that the human life-cycle starts with small incomes and then becomes more stable which requires individuals to plan carefully to ensure a more 
comfortable life in old age. The life-cycle hypothesis is important to evaluate the planning devised by newly married couples for selfcontrol and the efforts made to achieve better FWB in the future.

\section{Research Methods}

Fourteen Malay informants who live and work in the Klang Valley and have been married for three to five years were interviewed as a couple. Newly married couples refer to married couples in their first five years of marriage (McGinley, 2009; Moen, 2011). They were recruited through intensity sampling where informants search concentrated towards a small number of cases with rich information, knowledge and experiences of the phenomenon of interest (Patton, 1990). They are from the M40 group, dual-income families, aged between 25 and 40 , and this is their first marriage. Each couple went through three interview sessions that took between two to four hours. A series of interviews was conducted to achieve depth and richness of data to answer the research questions. The interview was recorded with the consent of the informants. All couples chose to be interviewed in the Malay language.

Upon completion of each interview session, data were transcribed verbatim. The transcript was translated into English then submitted to a certified translator for verification. Data sources are taken from interviews, observations and field notes. We observed the living conditions of informants (dwelling houses) and informants' living styles (in terms of clothing, accessories and home furnishing layouts) as these reflected the economic situation and spending habits of the couple. To ensure trustworthiness, member checking, data triangulation and theory triangulation were performed. The informants' statements were cross-examined through observation, field notes and documents (spending records, bank documents and list of monthly expenses) obtained from them. The use of observational data and field note aims to focus on 'natural setting' that facilitates the explanation of phenomena. The interview was conducted at the informant's home at the time on the date agreed upon. This study focuses on two theories to support the anticipated connection through various researcher and participants at different time and situation (Miles \& Huberman, 1994). The interpretation of the findings was enriched by using more than one theory to enhance the researcher's interest (Brandell, 2008). To reduce bias and avoid prejudice to informants' statements, the research procedure was clearly described (Yin, 2011) and informants were given access to research questions (Given, 2008). Then, the in-depth interviews were conducted to enrich the data (Chenail, 2011).

The instrument of inquiry is seven openended interview questions. Open-ended questions allow informants to share their ideas and insights, without leading them to specific feedback. Phenomenological methods were used in the transcriptional analysis. The analysis involved coding of phrases and identifying relationships between themes emerged, which were identified in the first stage. When a connection between themes appeared, the theme was clustered into a superordinate theme. The excerpts extracted from the data were examined according to a new theme using N-Vivo 12.

Data collection and analysis in qualitative research is discontinued once it reaches saturation level (Saunders et al., 2018). A qualitative study based on the phenomenological tradition where the sample size was either between 5 and 25 (Creswell, 1998) or consisting of at least 6 informants (Morse, 1994). The study stopped the informant's search after interviewing the seven couples and after transcribing the data and performing the coding process, it was clear that no new information was available. In-depth studies of specific ethnic groups using this method were supported by Leung (2015).

\section{Findings and Discussion}

Tracing young adults' road maps for FWB tends to focus on three inexorable themes. Findings show that income insufficiency drives couples to be cautious in spending and seek opportunities 
to increase income through side businesses and secure investments.

\section{Income Insufficiency}

Income insufficiency was the root cause for the inability to enjoy FWB today and motivated them to devise action plans. As higher education graduates, their income is between RM4,400 to RM8,200 which was only adequate for survival in the city. Thus, they agreed to distribute the household financial responsibilities where the husbands were responsible for a home loan or rent, groceries, bill payments and medical expenses, while the wives were more focused on personal care and children's needs. One informant said:

"Indeed, I decide on my own, [it is my] responsibility, err, Islam also teaches us to provide shelter, food and clothing for wife and children to the best of our ability, right?"

(Couple \#3-husband, session 1)

There were times when husbands often ran out of money before the end of the month. In desperation, the husbands had to borrow money from their wives. For that, the wives would postpone the purchase of personal necessities to meet the needs of the family and ensure that the bills were paid up until next month's pay. As one husband disclosed:

"Sometimes before the payday comes,

I run out of money, so I have to borrow from my wife (chuckle)".

(Couple \#2 - husband, session 1)

In addition, they acknowledged the need for savings in preparation for things beyond their control or emergency. Given the current financial situation, it is difficult to overstate they find other ways to make savings. They subscribed to the 'kootu funds' scheme with close friends. 'Kootu funds' are illegal in Malaysian law (Kootu Funds (Prohibition) Act, 1971). It is less secure because fraud can occur.
'Kootu funds' require a leader to hold his/her players' money. The amount of money was paid monthly by the players with the agreed amount. All the money collected was then paid monthly to each player according to the agreed-upon turn. These couples chose to take the money in the month they need it most, such as to renew the road tax and the birth of a new child. One informant said:

"We subscribe to the maximum amount, my monthly "kootu fund" is RM500. That's my planning, for the family or use during pregnancy. Usually, we will take it when it comes time to renew the road tax".

(Couple \#5 - husband, session 2)

Meanwhile, the couple \#5 admitted to still following the old-fashioned way of saving, which his mother used to do. He often hid some money in some places like under the folds of clothes in a wardrobe. He accentuated that he did not mean to hide the money from his wife but rather as a buffer in time of need.

"I like to hide my money (laugh), I don't keep it in hand, sometimes, I place it in my clothes but not in large numbers, sometimes I place it here, some amount, in the closet". (Couple \#5 - husband, session 2)

To save on spending, they chose to ride motorcycles to work. It was not only economical in terms of petrol, but it also prevented traffic congestion. They admitted this is a real challenge, especially when they saw most of their friends driving a luxury car. However, they need to be persistent because sacrifices have to be made today to achieve a higher level of FWB in the future. They do not keep up with their university friends on social media, fearing that it will be stressful when they see the luxury their friends highlighted on social media. An informant said:

“... these motorcyclists are usually the ones who just got a job but for me, 
it's easy for me to go to work right? I have a friend who drives a $B M W, m y$ other friend just bought a new Honda, they're the same level as me, which is, maybe their salary is about the same as mine. Err, the other one, just bought the new Renault Fluence, of course, I would be depressed. But I always say to myself, "it's okay”, err, I always say, "this is a sacrifice" I said [to my wife], "to struggle for a short while in order to gain something better in the future". (Couple \#1-husband, session 1)

The habit of saving and careful spending was among their preparations to enjoy FWB in old age. They are willing to let go of comfort today with the hope of accelerating their FWB. This attitude differed from previous studies (Ganesan, 2012; Knoll et al., 2012) which suggested that young people were not in control of their spending and were reluctant to save. Their behaviour is in line with the LCH theory which states that the human life cycle begins with a low-wage position. Over time, it becomes more stable with a higher position. Hence, careful planning is crucial to enjoying comfort in old age.

\section{Thrifty in Wisdom}

The second road map engaged by these couples is thrifty. The common practice is to make a price comparison before making any purchases. One informant said:

"I make a [price] comparison, "okay, this one, its price might be 20 cents per litre", which is priced at RM10.00, and then, the other one, its price might be RM1.00. Oish, this is expensive," so, I ask her to take the other one".

(Couple \#1-husband, session 2)

It appears that at the beginning of the marriage, the wives were dissatisfied with the attitude of their husbands. Disputes were often triggered by this. The husbands interrupted, saying their weakness was the failure to explain why it was necessary. It caused wives to feel unloved because many of their desires were not fulfilled. One informant confirmed it by stating:

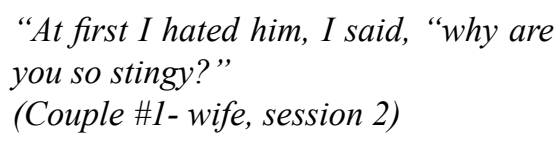

However, after a few years of marriage, they recognized that this was the spending method that saved them from getting into debt. Trust in husbands grew when their husbands gave flexibility in the purchase of makeup and clothing items. The husbands would bring the whole family to buy clothes and necessities for every festive season. The wives' understanding became clearer when they saw that their husbands were more concerned with the needs of the wives and children than themselves. This was evident when one informant said:

"When I was about to get
married, my father advised me
and I remember to this day. He said, as a man, we must always give in, the needs of wife and children must come first. That's why, when I see my wife always wearing two, three same clothes when we go to a wedding (laugh), I said "honey, let's buy new clothes this weekend" and yes, I bought her... one or two like that, while in fact, I also wore the same shirt over and over again, which I bought at the bundle (second-hand) shop (laugh)'. (Couplen \#6-husband, session 1)

To save more, they subscribe to loyalty cards to enjoy the rewards provided by shopping malls and hypermarkets and spend more during sales promotions. To avoid unplanned purchases, they prepared a pre-shopping list. As for electrical appliances and women's clothing, they preferred to shop online because while it was easy to make quality comparisons, it was also cheaper and saved time. One informant mentioned:

"Err, we shop according to the checklist, one hundred percent, but if there's a discount or something, we feel 
it's a good deal and we don't need to buy it next month, then we'll take it". (Couple \#4-wife, session 2)

Unlike the wives, the husbands prefer to buy clothes and shoes at the second-hand store for work and daily use. In addition to being reasonably priced, they are durable and of good quality.

According to one informant:

“...I buy second-hand items, leather, durable, err, as long as it's wearable, that's okay, no problem".

(Couple \#3-husband, session 2)

In terms of smartphone usage, it is mainly used for making/answering phone calls, messaging and socializing using 'Facebook' and 'Instagram'. They selected smartphones according to their suitability. Specifications and brands were not a priority. As for vehicles, they only have one locally-made car for family use. Besides, they still utilised the old motorcycles they used while studying at university. One informant uttered:

“...to me, the smartphone is to contact people, that's enough, I don't need more apps".

(Couple \#4 - husband, session 2)

The family also plays a role in reducing the financial burden of these couples. Couple \#1 just resumed the monthly payment for the car her father provided while studying at university, while couple \#2 was living in a house bought below the current market price from his brother. Whereas, couple \#3 was be able to pay the down payment for their house from a loan given by her grandmother. Couple \#4 was driving an old Perodua Kancil car which his father had given free. As for couple \#5, they rent a family home at a low rental rate. One informant reported:

"It's my dad's car, I took over the [monthly] payments".

(Couple \#1-wife, session 2)
Interestingly, couples \#3 and \#5 did not use credit cards. Whereas, for couples \#1, \#2 and \#4 only one person in their household held the credit card. The use of credit cards was limited to emergency purposes, contingent expenses that required large sums of money and for the purchase of petrol. For couples \#3 and \#5, though eligible, they do not want to, believing that it can lead to impulsive purchases. They worried that if not being able to handle it well could lead to an increase in debt. This is explained by one informant:

"Looking at other people. When we see our friends, using credit cards, the desire to spend is higher, because they can buy on credit, and then, in the end, they get a letter, stating that they have been blacklisted [for nonpayment], that's what happens". (Couple \#3 - husband, session 2)

Now, wives are more prudent in their spending, often seeking advice and permission from their husbands before making purchases despite spending their own money. One of the wives said:

"...if something that can be bought next month, I'll postpone it. Thank you for reminding me (smile while looking at her husband)".

(Couple \#4-wife, session 2)

Thus, another praiseworthy attitude that these couples have, which can indeed be exemplary to their age group is the power to control their desires. As the head of the family, the husbands managed to educate their wives. A common feature among all husbands is their belief in educating their wives in the Islamic way. The husbands explained that Islam forbids his followers to waste. This is in line with the word of Allah SWT in QS: Al-Israa' [17: 26-27], which means: "And give the relative his right, and [also] the poor and the traveller, and do not spend wastefully. Indeed, the wasteful are brothers of the devils, and ever has Satan been to his Lord ungrateful". While nodding, one of the wives agreed when her husband said: 
"No matter how big our fight, it won't take long, but indeed [I] have to be patient, and then after we perform the prayer, she follows behind me, once we perform prayer together, she will apologize, we as a man, we don't grudge, okay, move on".

(Couple \#1-husband, session 3)

According to Malton and Clarkson (2017), young adults experienced social pressures where they strived to be equal to friends in terms of spending because they did not want to be left behind. However, this study found otherwise as these young couples were wise in distinguishing between needs and wants. They were also judicious in distinguishing virtues and selfishness. They practised a modest, yet a tolerable lifestyle.

\section{Moonlighting}

Moonlighting refers to individuals who retain their primary job and at the same time take on additional work for pay (Amini-Philips, 2019). These couples were not merely dependent on income from their official occupations. They ventured into real estate on a part-time basis, bought gold bars intending to resell at high prices, took ASNB financing as a deposit to maturity and involved in small businesses. They took an initiative to learn from experts to avoid being deceived or lost. As one informant said:

\section{"I... seriously, I have no business experience ma'am, so, fear of making mistakes, we actually hmm... we attended the course... that course hmm... 'Success Magnet Seminar', well, it's quite expensive, but you know, at least it teaches us how to start our business and makes us feel confident to do business (chuckle)". \\ (Couple \#7-husband, session 2)}

Their determination is apparent when they also sacrificed their time to ensure their efforts were successful. The responsibility of taking care of the family is entirely up to the wife when the husband had to work overtime to serve the customers. It was explained by one informant:

"Irepair printing tools, I do itmanually
and I don't like to be disturbed while
working even though it might be at
the weekend. I say "if you want me to
stay at home, I may not have money",
Saturday, Sunday, err, sometimes at
night. My working hours for my part-
time job don't make sense. Sometimes
people call me to do some repair work
at night". (Couple \#5 - husband,
session 3)

According to them, although at first, what they were doing was purely to increase their family income. However, in reality, they earn more than that as they can afford to save money, provide their parents pocket money, and even have the opportunity to help less fortunate siblings. It turned out to be true when one of the informants stated:

"I used to sell 'nasi lemak' at work,
and we could save from the sales,
but in this new workplace, the rules
are different, [but] we plan to open
a burger shop when we move to our
new house in Puchong. For now, I'm
selling 'Coway'water filter (chuckle)".
(Couple \#4-wife, session 3)

Another admirable attitude in these couples is that they were not just thinking about themselves. The husbands adhere to Islamic principles: prioritise parents before their wives and children. In addition to providing financial assistance to parents, they also help siblings who have financial problems. One of the informants revealed:

"I have a plan to help my brother open
a restaurant, give him a start-up capital
because he's weak academically but
he's good at cooking".
(Couple \#1-husband, session 3)

It was following the word of Allah SWT in QS: Al-Baqarah [2:215] "They ask you, [O 
Muhammad], what they should spend. Say, whatever you spend of good is [to be] for parents and relatives and orphans and the needy and the traveller. And whatever you do of good-indeed, Allah is Knowing of it". This verse encourages mankind to be generous, and indeed Allah will reward those good with blessings.

Proven now their efforts have been fruitful. Couple \#1 was in the process of finding a tenant for a studio unit he bought in Cyberjaya and now was actively looking for opportunities to buy property at auction. Couples \#2, \#3 and \#4 already have several hundred grams of gold ingots. Meanwhile, couple \#5, the wife was actively selling women's necessities from scarves to makeup online while her husband was very active in the printing business which has been running for two years. Their earnestness was evident when the wife enunciated that she was currently raising money to rent a store to expand her business.

\section{"I like doing business, if I have some money in the future, I've always said, I'd like to open my own business. I said to my dad, the shop, there is a shop, in front there [refers to a shop located on a side street, near their home], err, "if nobody wants to rent it, I want to rent it dad", I want to open a boutique (laugh). That is my dad's shop, but he rents it to someone else". \\ (Couple \#5 - wife, session 3)}

Their imagination about future wealth accumulation, financial freedom, financial security and a higher level of FWB is not just a dream, but a rather well-thought-out statement that can be realised with effort and earnestness. They described the future confidently and organised the implementation steps wisely. One informant stated:

"I certainly feel the pain now! But I think, it's okay, in the future, it's going to be better. My friend, I see, her life is okay, but later in the future, her life will remain the same, just like that, err, I don't want [my] future life, to stop at that level only".

(Couple \#1 - wife, session 1)
Though they have not set goals for a certain period, they were confident that the efforts made today would give them tranquillity in old age, where they do not have to worry about debts and can enjoy the financial freedom. Their planning horizons revolved around long-term planning that is closely linked to the preparation of future economic strengthening. It included planning for savings, investments and future financial strengthening. It aligns with the utility theory: when individuals decide to postpone current satisfaction for future success, they were working to optimise investment to maximise expected future satisfaction.

\section{Conclusion}

FWB in their perspective is to identify specific realistic goals and plan steps to achieve them. A better FWB is achieved with a stable financial position and is able to break free from debt. The sacrifices made today were temporary, driven by dreams of achieving financial independence in the future. Efforts to regulate spending and formulate an additional income-generating strategy, are a road map towards greater FWB in the future. It is in line with the utility theory that for future-oriented time horizon individuals, they chose to sacrifice today's satisfaction for a higher level of contentment in the future. Their planning horizons were long-term. With the limited source of income, they strived to avoid the burden of debt and unplanned expenses. For now, the opportunity to save, be able to control debt, proficiently distinguishes between needs and wants and having a safe and secure investment for the future, was sufficient for the preparation to move towards greater FWB. Indeed, families who succeed in building their own safety nets are able to become self-reliant and make them less likely to seek outside help (Hamilton, Rothwell, Huang, Nam \& Dollar, 2020). Hence, to foster ongoing awareness and to complement policy implications at the academic level, this study proposes that the Department of Islamic Development Malaysia in collaboration with the Agency Counselling and Debt Management provides a special slot 
on financial management in the pre-marital course. Although this finding does not represent the Malay community in general, the positive attitudes of these couples need to be made public so that they can serve as a model for young people to follow. Moreover, this study has managed to uncover the noble values inherent in the Malay youth's lives through this small group.

\section{Acknowledgements}

This study is part of an ongoing $\mathrm{PhD}$ research at the University of Malaya, Faculty of Economics and Administration, and was supported by SLAB/SLAI (Skim Latihan Akademik Bumiputera/Skim Latihan Akademik IPTA).

\section{References}

Amini-Philips, C. (2019). Moonlighting activities and lecturers' wellbeing in Nigerian universities. Advances in Social Sciences Research Journal, 6(7), 339-346. doi: 10.14738/assrj.67.6762

Bentham, J. (1781). An introduction to the principles of morals and legislation.

Brandell, G. (2008). Using multiple theoretical perspectives to connect, clarify and convey research results. Retrieved from Lund University, Centre for Mathematical Sciences website: http://citeseerx.ist.psu. edu/viewdoc/download?doi=10.1.1.549663 $4 \&$ rep $=$ rep $1 \&$ type $=$ pdf

Castro-Gonzales, S., Fernandez-Lopez, S., Rey-Ares, L., \& Rodeiro-Pazos, D. (2020). The influence of attitude to money on individuals' financial well-being. Social Indicators Research, 148, 747-764. doi: 10.1007/s11205-019-02219-4

Chenail, R. J. (2011). Interviewing the investigator: Strategies for addressing instrumentation and researcher bias concerns in qualitative research. The Qualitative Report, 16(1), 255-262.
Creswell, J. W. (1998). Qualitative inquiry and research design: Choosing among five traditions. Thousand Oaks, CA: Sage Publications.

Dornbusch, R., \& Fischer, S. (1994). Macroeconomics (6th ed.). New York: McGraw-Hill.

Dutt, A. K. (2006). Consumption and happiness: Alternative approaches. Paper presented at the New Directions in the Study of Happiness, University of Notre Dame.

Falahati, L., \& Sabri, M. F. (2015). An exploratory study of personal financial wellbeing determinants: Examining the moderating effect of gender. Asian Social Science, 11(4), 33-42. doi: 10.5539/ass. v11n4p33

Frączek, B., \& Klimontowicz, M. (2015). Financial literacy and its influence on young customers' decision factors. Journal of Innovation Management, 3(1), 62-84.

Fong, J. H. (2020). Taking control: Active investment choice in Singapore's national defind contribution scheme. The Journal of the Economics of Ageing, 17, 1-11. doi: 10.1016/j/jeoa.2020.100249

Fulford, S. L., \& Schuh, S. D. (2015). Consumer revolving credit and debt over the life cycle and business cycle (Federal Reserve Bank of Boston Working Paper, No. 15-17). Retrieved from SSRN

Ganesan, A. S. (2012). Consumption, spending and investment behaviour of Malaysia generation $Y$ (Master of Business Administration). Universiti Tunku Abdul Rahman.

Garðarsdóttir, R. B., \& Dittmar, H. (2012). The relationship of materialism to debt and financial well-being: The case of Iceland's perceived prosperity. Journal of Economic Psychology, 33, 471-481.

Given, L. M. (2008). The sage encyclopedia of qualitative research methods (Vol. 1\&2). Sage Publications, Inc. 
Hamilton, L., Rothwell, D., Huang, J., Nam, Y., \& Dollar, T. (2020). Assets and household stability. In Welfare doesn't work, exploring the basic income guarantee (pp. 61-77): Palgrave Pivot, Cham.

Hasbullah, M. F. A., \& Razak, N. A. A. (2017). Divorce cases among Muslims: Demographic study of Daerah Barat Daya, Pulau Pinang. International Academic Research Journal of Social Science, 3(1), 154-158.

Holzmann, R., Ayuso, M., Alaminos, E., \& Bravo, J. (2019). Life cycle saving and dissaving revisited across three-tiered income groups: Starting hypotheses, refinement through literature review and ideas for empirical testingIZA Discussion Papers, No. 12655. Retrieved from https://www.econstor.eu/ bitstream/10419/207480/1/dp12655.pdf.

Horrocks, A. M. (2010). Financial management practices and conflict management styles of couples in great marriages (Master of Science). Utah State University. (733)

Hou, W. (2020). How accurate are retirees' assessments of their retirement risk? Boston College: Center for Retirement Research Retrieved from https://crr.bc.edu/wpcontent/uploads/2020/07/wp_2020-14.pdf.

Hudomiet, P., Hurd, M. D., Parker, A. M., \& Rohwedder, S. (2019). The effects of job characteristics on retirement (RAND Working Paper WR-1321). Retrieved from https://www.rand.org/content/dam/rand/ pubs/working_papers/WR1300/WR1321/ RAND_WR1321.pdf

Hurd, M. D., \& Rohwedder, S. (2013). Heterogeneity in spending change at retirement. Journal of the Economics of Ageing, 1-2, 60-71. doi: 10.1016/j. jeoa.2013.09.002

Jappelli, T., \& Modigliani, F. (2005). The agesaving profile and the life-cycle hypothesis. The collected papers of Franco Modigliani (Vol. 6, pp. 141-172). Cambridge, Massachusetts, London, England: The MIT Press.
Kim, H., Yoon, W., \& Zurlo, K. A. (2012). Health Shocks, out-of-pocket medical expenses and consumer debt among middle-aged and older Americans. The Journal of Consumer Affairs, 46(3).

Knoll, M. A. Z., Tamborini, C. R., \& Whitman, K. (2012). I do...want to save: Marriage and retirement savings in young households. Journal of Marriage and Family, 74(1), 86100. doi: $10.2307 / 41329661$

Leung, L. (2015). Validity, reliability, and generalizability in qualitative research. Journal of Family Medicine and Primary Care, 4(3), 324-327. doi: 10.4103/22494863.161306

Luna-Torres, M., McKinney, L., Horn, C., \& Jones, S. (2018). Understanding loan use and debt burden among low-income and minority students at a Large Urban Community College. Journal of Student Financial Aid, 48(1), 1-28.

Malaysian Insolvency Department. (2020). Statistical report retrieved from http://www/mdi.gov.my/index.php/ms/ about-us/resources/statistics

Malone, K., Stewart, S. D., Wilson, J., \& Korsching, P. F. (2010). Perceptions of financial well-being among American women in diverse families. Journal of Family and Economic Issues, 31, 63-81. doi: 10.1007/s10834-009-9176-5

Malton, C., \& Clarkson, T. (2017). Young adults and money management: Behaviours, attitudes and useful rules of thumb Money Advice Service (pp. 1-29). BritainThinks.

McGinley, D. M. (2009). Effects of career and marriage on newlywed individuals' marital and career satisfaction. (Doctor of Philosophy), University of Florida.

Miles, M. B., \& Huberman, A. M. (1994). Qualitative data analysis (2nd ed.). SAGE Publications.

Moen, D. A. (2011). Newlywed to established marriage: A longitudinal study of early risk and protective factors that influence marital 
satisfaction. (Doctor of Philosophy), Utah State University.

Morse, J.M.(1994). Designing funded qualitative research. In N. K. Denzin \& Y. S. Lincoln

(Eds.), Handbook of qualitative research (pp. 220-235). Sage Publications, Inc.

Patton, M. Q. (1990). Qualitative evaluation and research methods (2nd ed.). Sage Publications Inc.

Razak, M. I. M., Abidin, N. E., Yusof, M. A. M., Sakarji, S. R., \& Nor, K. M. (2014). Spending trends among youth in Malaysia. Journal of Economic and Development Studies, 2(1), 277-288.

Saunders, B., Sim, J., Kingstone, T., Baker, S., Waterfield, J., Bartlam, Burroughs, H., \&
Jinks, C. (2018). Saturation in qualitative research: Exploring its conceptualization and operationalization. Qual Quant, 52. doi: 10.1007/s11135-017-0574-8

Vosylis, R., \& Klimstra, T. (2020). How does financial life shape emerging adulthood? Short-term longitudinal associations between perceived features of emerging adulthood, financial behaviors, and financial well-being. Emerging Adulthood, 1-19. doi: $10.1177 / 2167696820908970$

Wickramasinghe, V., \& Fernando, D. (2017). Use of microcredit for household income and consumption smoothing by low income communities. International Journal of Consumer Studies, 41(6), 647-658.

Yin, R. K. (2011). Qualitative research from start to finish. The Guilford Press. 
